DOI https://doi.org/10.30525/978-9934-26-173-2-28

\title{
THE DIDACTIC WAYS OF ORGANIZING THE CULTUROLOGICAL TRAINING OF THE CADETS AT THE ESTABLISHMENTS OF HIGHER EDUCATION OF THE SYSTEM OF THE MINISTRY OF INTERNAL AFFAIRS OF UKRAINE
}

\section{Zelenska O. P.}

Doctor of Pedagogy, Full Professor, Professor of the Department of Foreign Languages and Culture of Professional Speech

Lviv State University of Internal Affairs

\section{Lviv, Ukraine}

Researching the content of the culturological training of the cadets at the establishments of higher education of the system of the Ministry of Internal Affairs of Ukraine conditions the search for the ways of organizing the educational process that can guarantee the stirring up, intensification and optimization of the educational and cognitive activity of the cadets, thus raise the efficiency of the whole educational process.

The culturological approach in the professional training of the cadets at the establishments of higher education of the system of the Ministry of Internal Affairs of Ukraine means the totality of the methodological methods that ensure the analysis of any sphere of the social and psychological life, particularly of the sphere of education and pedagogy, in the light of the culturological notions that form the system: culture, cultural samples, norms and valuables, everyday life, mode of life, cultural activity and interests. The culturological character of education is based on the uniqueness of every subject of the educational activity, on the provision of the conditions for their development in the context of the individual approach in the personality oriented and developing system of education that ensures the socio-cultural self-development of the personality. The aim of such education is people's culture, the content of it is culture as the environment, and the cultural creation is as the means of a person's development in culture [1, p. 71].

The culturological training of the cadets at the establishments of higher education of the system of the Ministry of Internal Affairs of Ukraine contributes to broadening their system of scientific knowledge, first of all, of philosophy, culturology, ethics, logics, psychology, the Ukrainian language and a foreign language that reveals the essence and the psychological and pedagogical conditions of forming and developing the moral beliefs, feelings, attitudes, culturological knowledge, skills, abilities and behaviour habits. In 
the course of the culturological training the purposeful psychological and pedagogical influence of the authorities, teachers, formal and non-formal groups takes place when the common educational forms, means and ways are specially utilized. A very important trend in the culturological training of the cadets is their independent work with the aim of improving the general, artistic and esthetic culture, developing the culturological qualities, highly cultural behaviour by means of self-education.

The peculiarities of higher education in the system of the Ministry of Internal Affairs of Ukraine are defined first of all by the fact that it is departmental education which is an organic element of the state educational system of Ukraine. This system is organized according to the multistaged training of the professional personnel, universally recognized national educational demands and international standards. ... Education of the future specialists of the organs of internal affairs of Ukraine is a very important component of the country activity regarding the formation of the proper state of law and order, public quiet, protection of rights, freedoms and legal interests of the citizens. Their professional training is considered to be one of the main sources of forming the qualified corps of the law enforcement officers and one of the most important branches of public relations [2, p. 148-149].

The personality oriented and proactive approaches to the problem of the culturological training of the cadets at the establishments of higher education of the system of the Ministry of Internal Affairs of Ukraine are among the main and most important approaches being the foundation for solving the research tasks.

The main didactic ways of increasing the efficiency of the culturological training of the cadets at the establishments of higher education of the system of the Ministry of Internal Affairs of Ukraine are as follows:

- ensuring the conformity of the means of education of the cadets with the content and means of their future professional activity;

- organizing the active and independent cognitive activity of the cadets in the process of acquiring professional knowledge, skills and habits;

- forming the cadets' mental activities and their acquiring the new and more effective means of the cognitive activity using the professional material;

- increasing the professional motivation and development of the professional orientation of the personality of the cadets on the culturological activity;

- developing and introducing into the process of education the system of the cognitive tasks, particularly, the problematic and outstripping ones. The creation and usage of the corresponding system of the professionally oriented problematic and non-problematic cognitive tasks using the elements of the 
outstripping, in our opinion, is the guarantee of the real development of the cadets' skills, abilities and personal qualities which are necessary for solving the professional tasks.

The modern approaches to stirring up the cognitive activity of those who study need the realization of the several groups of the positive factors in education. First of all it is connected with the motivation of education. The cognitive interest and the positive emotional attitude of the cadets to it are the most important motives. The interest in the subject and the emotional perception of the educational information are the most significant stimulators of mastering and remembering in the process of education. Because the outer causes act using the inner conditions, the insertion into the process of education not only of the cognitive sphere but also of the sensitivity personal one is the main tendency of forming education on the basis of the holistic personal experience [3]. Any human experience has its psychological content (structure) which must be taken into account in the process of teaching. Such subjective factors as the past experience, type, level and degree of the motivation, world outlook, the system of relations of the personality with the environment, the means of the past activity, etc. can be the inner conditions of manifesting the activity of the cadets. Solving the problem of stirring up, intensifying and optimizing the process of education of the future specialists is in forming their inner activity under conditions of having the active personal position in the process of education.

The problem of increasing the efficiency of education is often linked with strengthening its professional orientation. The approach to the educational situation as the system of the outer conditions in regards to the subject's cognition and at the same time as their reflection in consciousness conditions the necessity of such an organization of the educational and cognitive activity of the cadets which should be very close to their life and cognitive experience, should be in the zone of their intellectual development, on the one hand, and should be oriented towards the needs and demands of their future professional activity, on the other hand. Thus, the cadets must master their educational material, form their own skills, abilities and means of the mental activity, the features of the personality in the professional context. The didactic effect of education of the future law enforcement officers can be strengthened under conditions of the professional orientation of the whole process of education, including the culturological training as well, particularly of its means and modes. The activity and the initiative in education, the possibility of the creation of the new ideas and proposals of the cadets develop in the process of carrying out the various, as to the degree of independency, cognitive acts and conglomeration of their experience of the independent cognitive activity. During fulfilling the independent tasks the cadets' positive motivation to the process of education and the readiness to self-education are formed, the level 
of acquiring knowledge and forming the skills and abilities of the educational work increases, the effective formation of the means of the mental activity takes place.

But the achievement of such results is possible under conditions of the proper organization of the cognitive activity of the future specialists in the process of education, which foresees the high level of their independence and activity.

The professional training of the cadets at the establishments of higher education of the Ministry of Internal Affairs of Ukraine has the specific importance in forming the basis of the culturological development of the future officer of the organs of internal affairs. The psychological and cultural orientation of the personality, the motives and needs of the culturological selfeducation, interests and love of the profession of the law enforcement officer and its esthetic aspects are formed, the sense of duty and responsibility for the esthetically coloured carrying out the educational and service function is brought up. During professional education of the cadets at the establishments of higher education of the Ministry of Internal Affairs of Ukraine the accumulation of knowledge concerning all the issues of the social and civil life, culturology and culture, ethics and esthetics is carried out. The culturological training of the cadets as a psychological and pedagogical problem appears from the character and peculiarities of its modern state, it is initiated by its modern level and content.

Thus, the culturological training of the cadets at the establishments of higher education of the system of the Ministry of Internal Affairs of Ukraine must be considered to be as the motivated, purposeful, conditioned by the profession cognitive activity, such activity that can influence the sphere of the needs, interests, motives of the future law enforcement officers and contribute to their positive emotional attitude not only to the educational and cognitive activity, but also to the future professional activity.

\section{References:}

1. Иванова Т.В. Культура педагогического общения: монография. К.: ЦВП, 1999. 357 с.

2. Zelenska O.P. The culturological aspect of the professional training of the cadets at the higher educational establishments of the Ministry of Internal Affairs of Ukraine. Modern culture studies and art history: an experience of Ukraine and EU: collective monograph. Riga: Izdevnieciba «Baltija Publishing», 2020. P. 147-162.

3. Зязюн I.А. Сучасні дидактичні моделі і логіка учіння. Сучасні інформачійні технології та інноваційні методики навчання у підготовиі фахівців: методологія, досвід, проблеми: зб. наук. пр. Київ-Вінниця: ДОВ Вінниця, 2000. С. 4-7. 